\title{
Eukaryotic Cell
}

National Cancer Institute

\section{Source}

National Cancer Institute. Eukaryotic Cell. NCI Thesaurus. Code C12596.

A cell with a membrane-bound nucleus. 